drift, the result showing north-westerly course, the ship heeling over, and being heavily pressed by ice most of the time. The mental strain was heavy on some of us. The result of the drift during the last five months was 40 miles by tidal movement of ice; very rapid drift the last six months. Soundings pretty even-1 8 fathoms near Wrangel Land, which often visible 75 miles distant. The greatest depth was 80 fathoms; average depth, 35; bottom, blue mud; shrimps plentiful; meteoric specimens got from bottom; surface water temperature, $20^{\circ}$ above zero. The extremes of temperature of air were-cold, $58^{\circ}$ below zero (Fahrenheit); heat, about $44^{\circ}$ above. During the first winter the mean temperature was $33^{\circ}$ below zero, second winter $39^{\circ}$ below. During first summer mean temperature was $40^{\circ}$ above zero. The heaviest gale showed a velocity of 50 miles an hour, but such gales were not frequent. Barometric and thermometric fluctuations were not great. There were disturbances of the needle coincident with the auroras. Telephone (?) wires were broken by the ice movements. Winter's growth of ice was 8 feet. The heaviest ice seen was 23 feet thick. During the first week of the retreat from the feannette we drifted back 27 miles more than we could advance. The snow was nearly knee-deep. The naturalist's notes were saved, but the photo. graphic collection was lost with the ship. Lieut. Chipp's 2000 auroral observations were also lost." Thus it would seem that the Feannette, like the Tegetthoff, was caught in the ice soon after she entered on her task, and was drifted about in it for many months. The islands discovered are doubtless part of the Arctic archipelago which surrounds the Polar area, and of which Franz-Josef Land, the New Siberian Islands, \&c., are outliers. The full record of scientific observations promises to be of some value.

WE understand that the Admiralty are unwilling to send a national expedition in search of Mr. Leigh Smith and the Eira Expedition, but have at the same time expressed their readiness to propose a grant of $5000 \%$. towards the expense of a private expedition.

Dr. SCHWEINFURTH is said to have had a letter from the Marchese Antinori, telling him that he has heard in Shoa of the existence of a race of pirmies to the south-east of Kaffa. They are called Dakos by the Kaffa people, and Jukis by the Gallas. From their reported position it is thought probable that they belong to the same race as the Akkas.

M. Joseph MARTIN has on exhibition at the French Geographical Society a collection of photographs, maps, mineralogical specimens, \&c., which he has made during a long sojourn in Siberia, where he has been engaged in examining gold, silver, and other mines. During his journey he traversed the Ural, where he was chiefly occupied at the Beresofski gold-mine;, visiting also several mines of precious stones, iron, \&c. He next went to the $\mathrm{Ob}$, where he examined the mountains round Tomsk, afterwards visiting the gold and silver mines in the Altai. Having visited the Upper Yenisei, he made a geological examination of the Baikal region, and then descended the Lena to the mouth of the Aldan, up which he went for some distance. He also visited the Olekma and Vitim rivers, where gold-mines are being worked, and then made some mineralogical researches in the Stanovoi Mountains. He visited the Transbailial region and a part of Mongolia, and then followed the Chinese frontier from Kiachta to Vladivostock, after which he spent some time in mineralogical investigations on the Amur and the Ussuri, and in other parts of Russia, and Chinese Manchuria. M. Martin intends in April to start on a journey of exploration in the Kamchatka peninsula.

THE Dépôt de la Guerre at Paris has just published the first four sheets of a map of Africa, which, when finished, is to consist of sixty sheets. This map has been prepared by Capt. Lannoy.

In a paper which he has read before the French Geographical Society, Col. Veniukof, the well-known Russian traveller, estimates that a third of Asia, as well as a thirtieth part of Europe, still remains to be explored.

THE Lisbon Geographical Society has founded a section in the Azores.

DURING the past year the agents of the London Missionary Society in New Guinea have paid some attention to the previously unknown Maiva district, lying some distance to the west of Port Mcresby. In June the Rev. James Chalmers started a second time to visit the region, landing at Miria's village on the
Maiva cnast. After going to several villages on the coast and in the interior, he determined to visit Madu, the chief of Motu Lavao. Starting from the bight, he ascended a large creek with dense mangrove on both banks-a veritable bed of feverand then walked through the deserted village of Paitana to Motu Lavao, the path leading through a narrow tract of good country, with dense swamps on both sides. The village was found to be large, with clean and well-kept houses, but sitnated in a most unhealtby locality. At the end of July Mr. Chalmers again re-visited the Maiva district, in company with the Rev. W. G. Lawes and bis wife.

THE Society which was formed at Milan for the commercial exploration of Africa, has already examined the Barka plateau, and founded two stations at Bengazi and Derna, and this year it proposes to send agents to accompany an Arab caravan from the Mediterranean to Wadai, across the desert, and through the oases of Anjila, Jalo, Kufra, and Wanianga. The Society also hopes to obtain the necessary firmans from Constantinople to enable it to establish an agricultural colony to the east of the Barka plateau, and if possible, an attempt will even be made to explore the routes leading from Abyssinia towards Assab, the Italian settlement on the Red Sea.

\section{PHYSICAL NOTES}

M. Plan'e has found that the long process of "forming" his accumulators is shortened if they are warmed during charging. The temperature best for this purpose is between $70^{\circ}$ and $80^{\circ}$, at which limit the opposing electromotive force is somewhat less than when cold, and the resistance a great deal less. He does not find it advantageous to exceed this limit. We venture to suggest that the reason is that at boiling-point the oxygen and hydrogen are evolved in normal conditions, no ozone being produced. The electromotive force of oxygren against hydrogen is less than that of peroxide of lead against metallic lead, and far less than that of ozone against "nascent" hydrogen.

Prof. ANDREA NACCARI has re-examined the question of the unequal heating of the electrodes of a Holtz's induction machine by the passage of sparks. After carefully tabulating his results, be comes to the conclusion that in every case the negative electrode is less heated than the positive; that the heat developed in the spark is not affected by the nature of the meials of the electrodes; that with a constant striking.distance between the ends of the electrodes the heating effect in each electrode is proportional to the quantity of electricity that passes in unit time ; and that the quantity of heat thus developed by the passage of the electricity between the electrodes is very considerable.

Prof. Manfredo Bellati and Dr. $R$. Romanese have investigated the rapidity with which light modifies the electric resistance of selenium. The question has a practical bearing upon the construction of the photophone, since, if the time required to produce this change were considerable, the most rapidly vibrating sounds would become confused or inaudible in transmitting them. When light falling on a selenium cell was interrupted 1250 times per second, the resistance was practically the same as with a far less rapid interruption giving equal average illumination. All the experiments of these gentlemen led to the result that selenium behaves sensibly, as if the variation of resistance by the incidence of light were effected instantaneously.

M. LIPPMANN has applied his capillary electrometer to the study of the electric conductivity of shellac, gutta-percha, turpentine, petroleum, and other bodies, which, though insulators, when cold, begin to conduct as their temperature is raised. This subject was investigated in 1875 by Sir W. Thomson and by Mr. (afterwards Professor) Perry, more particularly in the one case of hot glass. In M. Lippmann's experiments a battery of one to forty voltaic cells was placed in a circuit in which the capillary electrometer was included, and in which the substance to be examined was interposed between two platinum plates. At ordinary temperatures the electrometer gave no indication, but moved forward as the temperature was raised to $100^{\circ} \mathrm{C}$. As the temperature fell, the substances examined resumed their former state as insulators. A paper on the same subject has, we observe, been recently communicated by $\mathrm{Mr}$. T. Gray to the Royal Society.

M. H. DUFour has made an interesting observation of no small importance in the theory of gaseous absorption of radiant 
energy. A mixture of chlorine and hydrogen gases diluted with air or oxygen combines slowly in light. Without air the mix. ture is exploded (as Tyndall has shown in well-known experiments) by exposure to white light, the chemical rays being most efficient. M. Dufour has examined the behaviour of this mixture as to its power of yielding radiophonic and photophonic sounds when illuminated by intermittent beams of different kinds, as in the researches of Graham Bell and Tainter. He finds that the loudest sounds occur when violet and ultra-violet rays are employed, no sound whatever being produced by red rays.

WE notice in the last number of the Fournal of the Russian Chemical and Physical Society (vol. xiii.), a paper, by $M$. Kraevitch, on the limit of rarefaction which might be obtained by means of mercury.pumps. M. Kraevitch affirms that in such a pump the tube will always remain filled with vapours of mercury, the elasticity of which, at ordinary temperatures, is no less than 0.02 millimetre; the use of desiccative substances cannot make these vapours disappear, as new vapours are immediately formed agaill. He contests therefore the idea that Mr. Crookes might have obtained in his experiments so low a pressure as 0.00004 metre ; and observes that M'Leod's gauge can measure the elasticity of a permanent gas (admitting that the law of Mariotte were true at such low pressures), but that it does not give the elasticity of the vapours of mercury. After a sketch of different air-pumps, he recommends that of Prof. Mendeleeff, with some modifications of his own, the most important of which is intended to eliminate the inconvenience which Mendeleeff's pump has in common with that of Sprengel, namely, the adhesion of an airfilm to the glass-tube at low pressures. The rarefaction of the air, he says, can be carried in this pump so far as to reduce the elasticity of the permanent gas to $0^{\prime} 0002$ millimetre, the pressure of the vapours of mercury always remaining, however, no less than 0.02 millimetre at the usual temperature of our rooms. In a few hours the rarefaction may be produced as to show the fluorescence of glass at the negative pole and the other phenomena described by Mr. Crookes, and even to stop the transmission of electricity.

\section{THE PRIZES OF THE PARIS ACADEMY}

THE following is, in brief, a list of the prizes offered in connection with specified subjects in $\mathbf{1} 882$ and following years:-In 1882: Grand prize of the Mathematical Sciences (medal worth $3000 \mathrm{fr}$.): Theory of the decomposition of whole numbers in a sum of five squares. Extraordinary prize of $6000 \mathrm{fr}$. : Progress increasing the efficiency of the naval forces. Plumey prize (medal, $2500 \mathrm{fr}$.): Improvement of steam-engines, or of steam-navigation otherwise. Damoiseau prize (medal, I0,000 fr.): Revision of the theory of Jupiter's satellites. Grand prize of the Mathematical Sciences (medal, $3000 \mathrm{fr}$.) : Experimental and theoretical study of the elasticity of one or several crystalline snbstances. Bordin prize (medal, $3000 \mathrm{fr}$.) : Origin of atmospheric electricity and cause of phenomena in thunderclouds. Desmazières prize (medal, I600 fr.): Best work in cryptogamy. Vaillant prize (medal, $4000 \mathrm{fr}$.): Inoculation as a prophylactic in contagious diseases of domestic animals. Grand prize of the Physical Sciences (medal, $3000 \mathrm{fr}$.) : Distribution of marine animals on the French coast. Du Gama Machado prize (medal, I $200 \mathrm{fr}$.) : On coloured parts of the tegumentary system of animals, or on the fecundating matter of animated beings. Breant prize (interest on 100,000 fr.) : Cure of Asiatic cholera. Godard prize (medal, Iooo fr.) : Anatomy, physiology, and pathology of the genito-urinary organs. Lalle. mand prize (I800 fr.): Work on the nervous system. Gay prize (2500 fr.): Marine lacustrine and terrestrial deposits on the French coasts in the present period, and especially since the Roman epoch. In addition, there are the Montyon prize in Mechanics, the Lalande and Valz prizes in Astronomy, and several others. Then in 1883 : Fourneyron prize $\left(500 \mathrm{fr}_{0}\right)$ : Different modes of transmission of force to a distance. Grand prize of the physical sciences (medal, $3000 \mathrm{fr}$.): Geological description of a region of France or Algeria. De la Fons Melicoque prize (300 fr.) : Botanical work on the North of France. Bordin prize $(3000$ fr.) : Influence of medium on the structure of vegetating organs; variations of terrestrial plants grown in water, and of aquatic plants in air; explain by direct experiments the special forms of some species of maritime flora. Bordin prize (medal, $3000 \mathrm{fr}$.) : Palæontology of France or Algeria. Grand prize of the physical sciences (medal, $3000 \mathrm{fr}$.): Histological development of insects during their metamorphoses. Alphonse Penaud prize (3000 fr.) : Aërial locomotion. In I884: Sener prize (7500 fr.): On genera embryology applied as much as possible to physiology and medi cine. In 1885 : Dusgate prize (2500 fr. ): Diagnostic signs of death and means of preventing precipitate inhumation. In I 886 the Jean Renaud prize will be awarded for the most meritorious work during five years.

\section{SYMBIOSIS OF ALGAE AND ANIMALS}

$A$ CORRESPONDENT sends us the following as an epitome of $\mathrm{K}$. Brandt's experiments on the green bodies found in the bodies of Hydra, Spongilla, Stentor, \&c. :-

When the green bodies are removed from these organisms by crushing, they are found not to be entirely and uniformly green like the chlorophyll-bodies of plants; in addition to the green substance they consist also of colourless protoplasm. Treatment with hæmatoxylin always reveals a definite cell-nucleus; and the same is the case if first killed by $0^{\circ} 2$ per cent. chromic acid or I per cent. superosmic acid, then freed from chlorophyll by alcohol, and finally treated with solution of hæmatoxylin. These green bodies do not therefore correspond to the chlorophyllbodies of algæ, but are themselves independent organisms, unicellular algæ. To those found in the animals named above the author gives the generic name Zoochlorella, to those which occur in the Radiolaria, Actiniz, \&c., the name Zooxanthella. Experiment proved that they are capable of carrying on an independent existence after removal from the animal in which they are found, and are able to produce starch-grains. They can also enter into the bodies of other animals which feed on those that contain them. The physiological function of these algæ was investigated in the case of those which form the well-known "yellow cells" of the Radiolaria. These were found to be of service in supplying food to the host, which thrives best in perfectly pure filtered water. So long as the animals contain few or no green or yellow algæ, they are nourished, like true animals, by the absorption of solid organic substances; but as soon as they conrain a sufficient quantity of these algæ, they are nourished, like true plants, by assimilation of inorganic substances. In the latter case the alger which live in the animals perform altogether the function of the chlorophyll-bodies of plants. Finally the author compares the mode of life of these Phytozod (as he terms the animals which subsist on the algæ contained within them) with that of Lichens. With the Phytozoa there is, however, this remarkable peculiarity, that morphologically it is the alga, physiologically the animal which is the parasite.

\section{NOTES ABOUT SNAKES}

$A$ SERPENT'S first instinctive impulse of self-preservation, like that of every other animal, lies in escape ; probably a more nervous creature does not exist. If surprised suddenly, or brought to bay at close quarters, it may be too terror-stricken to attempt flight; then it bites, following a curious general rule which seems to obtain throughout nearly the whole animal world, from a passionate child downward, no matter what the natural weapons of offence may be. Young Felida will keep their talons sheathed until they have exerted all possible force with their soft milk-teeth, and a lizard will seize the hand which restrains it with its insignificant little jaws, when its tail or claws might inflict far more injury. The Boidce never use their constrictive powers in self-defence (unless they are gripped), and it seems probable that if a venomous snake's fangs lay in its tail, it would use its teeth first when attacked before bringing them into play. Indeed it must be remembered that very few animals are provided with exclusively defensive weapons, and that the python's enormous strength in constriction, the viper's poison apparatus, the lion's teeth and claws, and the electric discharge of the gymnotus are given them primarily for the purpose of securing their food.

A snake runs away, walking along on the points of its numerous ribs with a rapidity which can only be appreciated by those who have seen a long one-Herpetodryas, for instanceescaping in the open or over the bushes when alarmed, its speed being further increased by the body being drawn up at intervals into folds, which, being extended, shoot the head forward. This is the swiftest mode of progression of which a snake is capable, and is, as I have said, difficult to be realised from the spectacle of these reptiles in cages; the Brazilian neck-marked snake (Geopytas collaris), at the Zoological Gardens, will perhaps con- 